
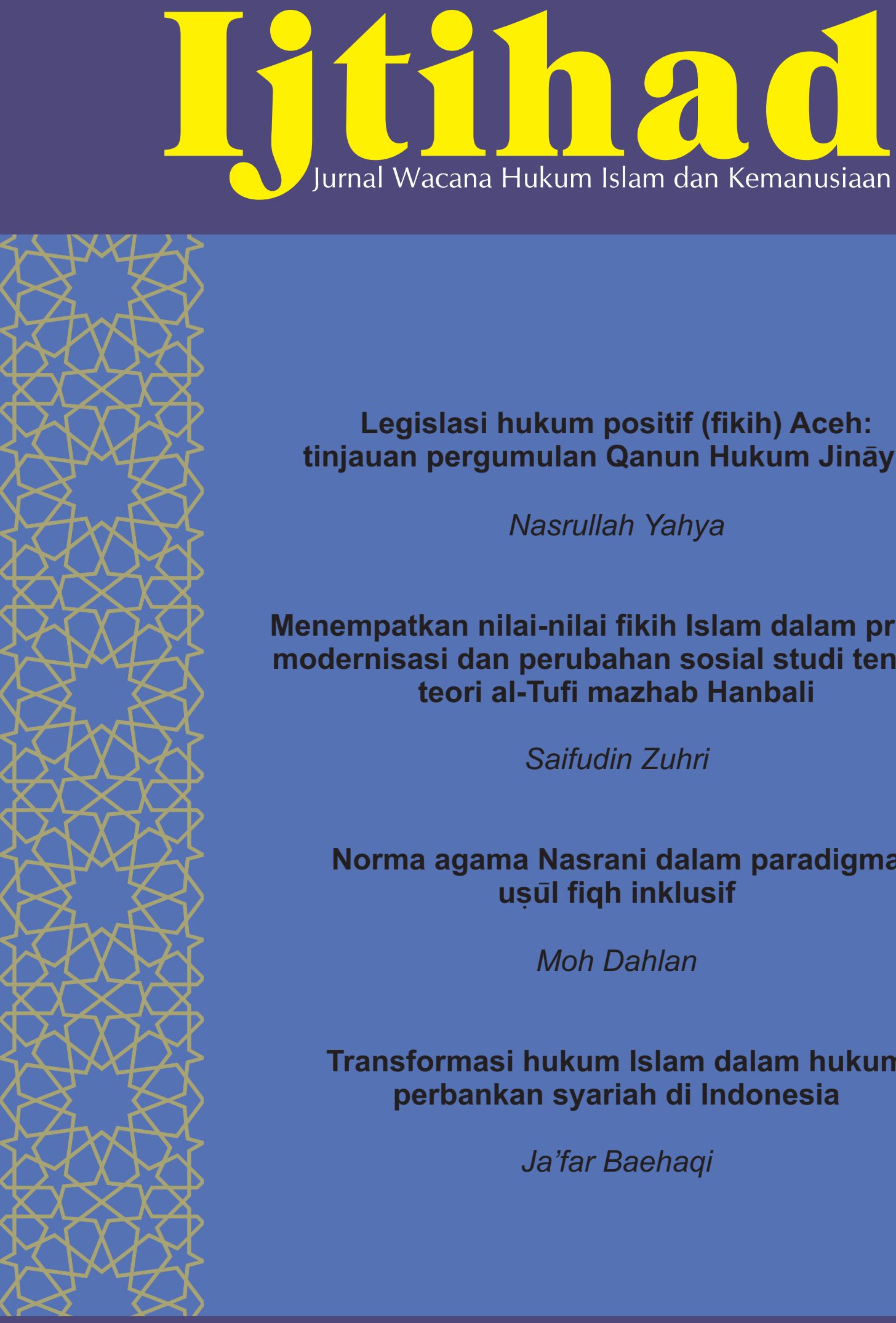

Legislasi hukum positif (fikih) Aceh: tinjauan pergumulan Qanun Hukum Jināyāh

\author{
Nasrullah Yahya
}

Menempatkan nilai-nilai fikih Islam dalam proses modernisasi dan perubahan sosial studi tentang teori al-Tufi mazhab Hanbali

Saifudin Zuhri

Norma agama Nasrani dalam paradigma ușūl fiqh inklusif

Moh Dahlan

Transformasi hukum Islam dalam hukum perbankan syariah di Indonesia

Ja'far Baehaqi 


\section{Ijtihad \\ Vol. 14, No. 2, Desember 2014}

\section{Daftar isi}

Legislasi hukum positif (fikih) Aceh: tinjauan pergumulan Qanun Hukum Jināyāh

Nasrullab Yabya • 149-166

Menempatkan nilai-nilai fikih Islam dalam proses modernisasi dan perubahan sosial studi tentang teori al-Tufi mazhab Hanbali

Saifudin Zubri • 167-187

Norma agama Nasrani dalam paradigma uṣūl fiqh inklusif

Mob Dablan • 189-209

Transformasi hukum Islam dalam hukum perbankan syariah di Indonesia Ja'far Baehaqi • 211-230

Akar, posisi, dan aplikasi adat dalam hukum

Abwan Fanani - 231-250

Bayang-bayang teori keagenan pada produk pembiayaan perbankan syariah Misnen Ardiansyah • 251-269

Dimensi politik hukum dalam perkembangan ekonomi Islam di Indonesia Bambang Iswanto • 271-284

Book Review:

Kritik otoritas pemaknaan hadis menuju masyarakat Islam berkemajuan Mubammad Irfan Helmy • 285-297 



\title{
Akar, posisi, dan aplikasi adat dalam hukum
}

\author{
Ahwan Fanani \\ Pascasarjana UIN Walisongo Semarang \\ E-mail:aristofanfanani@yahoo.com
}

\begin{abstract}
Adat (custom) is a polemical topic in Islamic law. The development of Islamic law since the era of Prophet Muhammad has shown the important role of adat. Islamic law was formulated in accordance or in opposition to the custom of Arabs. However, classical Islamic legal theory (ușul fiqh) does not consider it in legal argumentation. Its role is recognized in qawa $\bar{c}$ id fiqhiyyah (principle of practical law) as one of five main principles. It is included in non-agreed legal argument. The paper is aimed to reveal the place of custom in Islamic law from the era of prophet to the contemporary era, especially in Islamic legal theory, in the principles of Islamic law, and in Islamic court according to manual book. This paper concludes that custom plays crucial role in elaborating Islamic law in practice. Custom has been acknowledged by Islamic scholars, especially by those of Hanafite and Malikite schools, as important part of Islamic law. However, they limites the role of custom in term of private law. The custom was never be discussed in term of rites and folklore, as it is popular now. The custom can still plays important role in Islamic private law or even in alternative dispute resolutions as far as traditional authority is needed and acknowledge by Islamic communities.
\end{abstract}

Adat (custom) merupakan polemik dalam hukum Islam. Perkembangan hukum Islam sejak zaman Nabi Muhammad telah menunjukkan peran penting dari adat. Hukum Islam dirumuskan sesuai atau bertentangan dengan kebiasaan orang-orang Arab. Namun, teori hukum Islam klasik kita (uṣul fiqh) tidak mempertimbangkan dalam argumentasi hukum. Perannya diakui dalam qawā cid fiqhiyyah (prinsip hukum praktis) sebagai salah satu dari lima prinsip utama. Hal ini termasuk dalam argumen hokum yang tidak disepakati. Artikel ini bertujuan untuk mengungkapkan tempat adat dalam hukum Islam dari era Nabi ke era kontemporer, khususnya dalam teori hukum Islam, dalam prinsip-prinsip hukum Islam, dan di pengadilan Islam menurut buku manual. Tulisan ini menyimpulkan bahwa Adat memainkan peran penting dalam menguraikan praktek hukum Islam. Adat telah diakui oleh ulama Islam, terutama oleh orang-orang dari Mazhab Hanafi dan Maliki, sebagai bagian penting dari hukum Islam. Namun, mereka membatasi peran adat dalam hal hukum privat. Kebiasaan ini tidak pernah dibahas dalam hal ritual dan cerita rakyat, seperti yang populer sekarang. Kebiasaan masih bisa memainkan 
ljtihad, Jurnal Wacana Hukum Islam dan Kemanusiaan, Volume 14, No. 2, Desember 2014: 231-250

peran penting dalam hukum privat Islam atau bahkan dalam resolusi sengketa alternatif sejauh otoritas tradisional dibutuhkan dan diakui oleh masyarakat Islam.

Keyword: Custom (adat/'urf); Islamic legal theory; The principle of Islamic law; Prospect

\section{Pendahuluan}

Islam dibangun di atas dua landasan utama, yaitu al-Qur'an dan sunnah. Keduanya membentuk sumber dasar hukum Islam (al-masädir al-tasbri') yang disepakati oleh para ulama. al-Qur'an dan sunnah menjadi basis bagi legitimasi sumber-sumber hukum yang lain, seperti

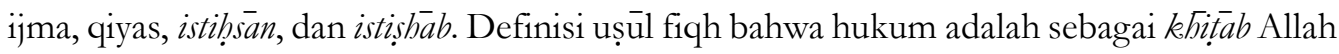
(tuntutan firman Tuhan), yang menjadi unsur utama hukum Islam, merujuk kepada dua sumber utama tersebut.

Kajian hukum Islam umumnya menitikberatkan kepada upaya deduksi hukum dari sumber-sumber dasar tersebut. Hukum Islam adalah upaya manusia untuk memahami kehendak Allah untuk mengatur kehidupannya, baik yang terkait dengan urusan ibadah maupun hubungan mumalah. Pemahaman tekstual terhadap sumber hukum dasar menempati posisi pertama karena merepresentasikan secara eksplisit kbițāb Allah.

Kendatipun al-Qur'an menyatakan bahwa ajaran Islam telah sempurna, hal itu tidak berarti bahwa semua persoalan telah dijawab secara teknis oleh al-Qur'an dan sunnah. Banyak perkembangan masyarakat yang belum disentuh pemecahan praktisnya oleh al-Qur'an. Hal itu merupakan sebuah kewajaran karena teks al-Qur'an dan hadis terbatas (mutanăhiyyah), sementara problem manusia tidak terbatas (ghair mutanähiyyah) (Rushd, 1989: 5).

Kesempurnaan Islam terletak kepada nilai dasarnya. Nilai dasar Islam yang universal bersifat sempurna. Segala persoalan kehidupan telah tercakup dalam nilai-nilai dasar Islam, baik yang menyangkut akidah (keimanan), ibadah (ritual), akhlak (ajaran moral), maupun mumalah (segala hal yang menyangkut hubungan antara manusia).

Para ulama menyadari bahwa penerapan ajaran Islam berdasarkan analisis al-Qur'an dan sunnah secara tekstual saja tidak akan memadai untuk mencakup seluruh problem manusia. Karena itu, muncul berbagai kreasi ulama untuk tetap menjangkarkan semua persoalan kepada sumber-sumber hukum Islam melalui suatu metode. Ada sebuah keyakinan di kalangan umat Islam bahwa meskipun rumusan praktis al-Qur'an dan hadis terbatas, tetapi 
nilai-nilai yang dikandungnya bersifat universal, berlaku dimana saja, dan dapat diterapkan ke dalam berbagai kasus baru. Untuk itu, muncullah qiyas (deduksi-analogis), yaitu upaya menyeberangkan hukum dari sebuah kasus yang telah memiliki landasan dalil kepada kasus yang belum ada landasan dalilnya.

Melalui qiyas, berbagai kasus baru diberi justifikasi hukum melalui penelitian tentang adanya kesamaan alasan hukum yang melatari kasus-kasus tersebut. Qiyas pada dasarnya adalah upaya menemukan nilai dasar dari hukum suatu persoalan yang telah memiliki landasan dalil sehingga nilai dasar tersebut dapat digunakan untuk menentukan hukum kasus-kasus baru. Zakat profesi adalah salah satu contoh bagaimana ketentuan zakat diperluas karena tuntutan nilai keadilan.

Dalam tradisi hukum Islam dikenal dua buah kaidah, yaitu kaidah uṣūl fiqh dan kaidah fikih. Kaidah uṣū adalah seperangkat kaidah tentang bagaimana mencari hukum yang terkait dengan perbuatan manusia dari sumber-sumber hukum taf̣sil Islam, yaitu dalil-dalil dari al-Qur'an dan sunnah rinci, sehingga obyeknya adalah dalil shari; sedangkan kaidah ușulobyeknya adalah perbuatan mukallaf dengan detail persoalan-persoalan fikih. Kedua kaidah tersebut saling melengkapi karena kaidah ushul merupakan instrumen untuk memahami dalil hukum, sedangkan kaidah fikih instrumen untuk mencari pola dan prinsip penyelesaian hukum praktis dari kasus-kasus yang telah diselesaikan dengan menggunakan kaidah ushul (al-Nadwi, 1991: 59-60).

Sementara itu, kaidah fikih merupakan kaidah penerapan hukum. Kaidah fikih memberikan landasan bagaimna sebuah hukum diterapkan dan bagaimana prinsip-prinsipprinsip penerapanannya, khususnnya apabila muncul kasus-kasus lapangan yang bersifat sangat teknis. Dalam kaidah fikih terdapat lima kaidah utama: Segala perbuatan ditentukan oleh tujuannya; Bahaya harus dihilangkan; Kesulitan membawa kepada kemudahan (keringanan hukum); Keyakinan tidak bisa dihilangkan dengan keraguani; Adat menjadi sarana menetapkan hukum (al-Suyuti, t.th.: 5-dst).

Lima kaidah tersebut membentuk prinsip dasar kaidah fikih. Dari lima kaidah tersebut dapat diturunkan kembali kaidah-kaidah hukum yang lain.

Yang menarik dari dua kaidah di atas, yaitu kaidah ușul dan kaidah fikih, adalah dimasukkannya kebiasaan ('urf/adat) sebagai dalil hukum (dalam kaidah uṣü) dan sebagai kaidah mayor (dalam kaidah fikih). Itu berarti dalam taraf tertentu hukum Islam mengakui 
ljtihad, Jurnal Wacana Hukum Islam dan Kemanusiaan, Volume 14, No. 2, Desember 2014: 231-250

institusi "kebiasaan" dan tradisi sebagai salah satu institusi yang penting dalam pembuatan keputusan hukum. Kenyataan tersebut menunjukkan bahwa keberadaan kebiasaan dan adat tidak bisa dipertentangkan secara diametral dengan syariat, melainkan pada banyak kesempatan menjadi elemen dalam penjabaran syariat itu sendiri.

Masuknya adat atau kebiasaan dalam struktur hukum Islam hanya akan dipahami apabila posisinya dalam hukum Islam didefinisikan secara jelas. Dengan cara itu, pemilahan antara syariat dan adat secara diametral pada taraf tertentu adalah pemilahan yang ilusif karena keduanya berdampingan dan saling mengisi.

Hal senada disampaikan oleh Ibnu Qayyim al-Jauziyyah. Ibnu Qayyim menolak adanya pembedaan secara diametral antara hukum Islam (syariat) dengan hukum hasil kebijaksanaan pemerintah dan hakim pengadilan (siyasab). Bagi Ibnu Qayyim, pemilahan yang tepat adalah pemilahan antara keadilan dan kezhaliman. Apabila sebuah putusan hukum adil, ia adalah bagian dan representasi dari syariat itu sendiri. Sebaliknya, apabila sebuah keputusan tidak adil, maka ia adalah kezhaliman, bukan syariat (al-Jauziyyah, 1994, Juz II: 121).

Tulisan ini adalah sebuah upaya penjabaran kembali posisi adat atau kebiasaan dalam hukum Islam. Munculnya upaya untuk mengapresiasi adat sebagai sarana penjabaran hukum Islam tidak bisa disangkal lagi merupakan tantangan bagi para pengkaji dan pakar hukum Islam untuk mendudukkan adat atau urf dalam porsinya yang tepat. Pemahaman mengenai posisi adat dalam hukum Islam akan memperjernih relasi keduanya dalam ranah hukum praktis.

\section{Adat dalam pembentukan hukum Islam}

Seorang peneliti sejarah hukum Islam, Noel James Coulson, menyatakan bahwa sebenarnya hukum Islam tidak sepenuhnya menghapuskan adat masyarakat, khususnya masyarakat Arab tempat turunnya wahyu. Ada elemen-elemen yang memang digantikan oleh syariat, tetapi banyak pula elemen-elemen yang dipelihara oleh syariat Islam karena dipandang tidak menyalahi nilai dasar Islam (Lihat Coulson, 1960).

Pengkajian terhadap pola-pola hubungan antara adat (Arab) dengan ajaran Islam menunjukkan adanya tiga ragam pola hubungan ajaran Islam dan adat, yaitu pola penggantian, pola modifikasi, pola adopsi. Ketiga pola akan menjelaskan bagaimana hubungan ajaran Islam dengan adat masyarakat. 


\section{Pola pembatalan (penggantian)}

Pola penggantian yang diberlakukan oleh Al-Qur'an adalah pola dimana adat digantikan oleh Al-Qur'an atau sunnah sehingga ajaran Islam mengenai sebuah kasus dapat dibedakan dengan adatnya. Ada beberapa contoh pola penggantian adat oleh syariat.

Pertama, dalam tradisi Arab, adopsi anak mengakibatkan perpindahan hubungan genealogi anak dari orang tua asli kepada orang tua barunya. Apabila seorang anak menjadi anak angkat, maka ia akan memperoleh nama belakang dari ayah angkatnya. Dengan demikian pengangkatan anak mengakibatkan berpindahnya nasab (hubungan kekeluargaan) dari ayah asli kepada ayah angkat.

Keadaan tersebut berubah ketika Rasulullah menikahi Zainab binti Jahsyi, mantan isteri anak angkatnya, Zaid Bin Haritah. Zaid bin Haritah adalah mantan sahaya Rasulullah yang beliau angkat menjadi anak. Awalnya orang-orang Arab memanggil Zaid dengan Zaid bin Muhammad. Kemudian Al-Qur'an surat al-Aḩzāb ayat 4-5 membatalkan penisbatan anak angkat (adopsi) kepada orang tua angkat. Dengan demikian, pernikahan Nabi Muhammad dengan Zainab, janda Zaid, adalah sah berdasarkan wahyu (Al-Sabuni, 1999: 187).

Jadi, tradisi adopsi Arab yang mengakibatkan berubahnya nasab dari ayah asli ke ayah angkat dihilangkan oleh Al-Qur'an. 'Ali al-Sabunimenegaskan bahwa adopsi dengan mengubah jalur nasab menjadi praktek yang dilarang oleh Islam. Alasan pembatalan tersebut dapat ditemukan dalam hadis Rasulullah: "Barangsiapa mendakwakan diri selain kepada ayahnya dan menisbatkan diri kepada selain walinya, baginya laknat Allah, Malaikat, dan seluruh manusia. Allah tidak akan menerima taubat dan fidyah-nya (Al-Sabuni, 1999: 186, 191).

Pola yang sama berlaku dalam bidang pernikahan, yaitu poligami. Dalam tradisi Arab, poligami adalah sebuah kebiasaan yang normal. Adat tidak memberikan batasan maksimal jumlah isteri yang boleh dinikahi. Dengan turunnya surat al-Nisā' ayat 3 terjadilah pembatalan poligami tak terbatas. Poligami yang tadinya tidak membatasi jumlah isteri yang boleh dinikahi, kemudian hanya dibatasi sampai kepada empat saja, dengan ketentuan harus adil. Rasuluilah kemudian memerintahkan agar orang-orang yang memiliki isteri lebih dari empat untuk menceraikan istrinya kecuali empat saja (Al-Syaukani, 1994, Juz I: 528). 
ljtihad, Jurnal Wacana Hukum Islam dan Kemanusiaan, Volume 14, No. 2, Desember 2014: 231-250

\section{Pola adaptasi modifikasi}

Pola adaptasi adalah pola dimana adat yang awalnya dipandang tidak sesuai dengan nilai ajaran Islam dimodifikasi sehingga sesuai dengan nilai dan semangat ajaran Islam. Pola adaptasi dapat ditemukan dalam bidang waris. Menurut adat Arab pra-Islam, anak kecil dan perempuan tidak berhak menerima waris (Sabiq, 1995, Juz III: 424).

Adat tersebut lahir dari masyarakat Arab yang patrilineal, yang menganut sistem keluarga besar (extended family), dan yang hidup dalam masyarakat badui. Apabila si mati meninggalkan anak perempuan, pamannya akan mengambil seluruh harta ayahnya. Si anak perempuan tersebut akan dinikahkan oleh si paman dan kalau ia kaya hartanya diambil oleh paman. Sebuah kasus terjadi dan mengubah adat Arab tersebut menjadi sebuah tradisi khas Islam.

Seorang lelaki dari kalangan Anshar, namanya Aws bin Thabit, wafat. Ia meninggalkan dua orang anak perempuan dan seorang anak laki-laki yang masih kecil. Kemudian datanglah anak paman mereka kepada Rasulullah dan mengambil seluruh warisan Aws. Kemudian isteri Aus datang mengadu kepada Rasulullah. Turunlah surat al-Nisā', ayat 127 yang menegaskan adanya ketentuan mengenai hak perempuan.

Rasulullah kemudian mengutus orang dan menyampaikan agar warisan itu tidak dipindahtangankan. Beliau mengatakan bahwa telah turun wahyu yang menyatakan bahwa untuk laki-laki dan perempuan ada bagian (waris) (Al-Syaukani, 1994, Juz I: 528). Dengan turunnya ayat tersebut, hak-hak perempuan dilindungi oleh hukum Islam. Para ahli waris, yang di masa pra-Islam mengambil seluruh bagian diberi posisi sebagai 'așābah, yaitu penerima warisan yang mendapat bagian apabila harta warisan, setelah dibagi kepada ahli waris yang diberi ketentuan bagian oleh Al-Qur'an (asḩ̧ăb al-furüd), masih tersisa (Coulson, 1960: 15-16).

Pola modifikasi juga terjadi dalam bidang pernikahan. Dalam tradisi Arab, menurut Aisyah, ada beberapa macam pernikahan. Pertama adalah pernikahan seperti umumnya saat ini. seorang laki-laki datang kepada wali seorang perempuan, menyerahkan mahar, lalu menikahi perempuan itu.

Kedua, nikah istibdāa . Seorang laki-laki yang sudah bersih dari haid untuk mendatangi laki-laki lain dan bersetubuh dengannya. Hal itu dilakukan untuk memperoleh keturunan. Setelah perempuan tadi disetubuhi oleh laki-laki lain tersebut, suaminya tidak akan mengumpulinya sampai muncul tanda-tanda kehamilan. Apabila tanda-tanda kehamilan 
tampak, barulah suami perempuan itu akan menyetubuhinya.

Ketiga, sejumlah laki-laki, kurang dari sepuluh orang, berkumpul. Mereka semua menyetubuhi seorang perempuan. Apabila perempuan tadi hamil dan melahirkan anak, ia lalu mengundang para lelaki tadi. Ia akan memilih salah satu dari para lelaki tersebut yang ia sukai dan anaknya ia nasabkan kepada lelaki terpilih itu.

Keempat, orang laki-laki banyak berkumpul di suatu tempat. Di situ ada beberapa perempuan di tenda dengan tanda bendera ditendanya. Para lelaki tersebut akan masuk ke tenda yang ia mau dan menyetubuhi perempuan yang ada. Apabila salah seorang atau beberapa perempuan tersebut hamil dan melahirkan anak, mereka akan mengundang para lelaki tersebut. mereka lalu memilih siapa bapak si bayi berdasarkan kemiripan dengan si bayi dan menasabkan si bayi kepada laki-laki terpilih (Sabiq, 1995, Juz II: 104-105).

Dengan datangnya Islam, hanya satu model pernikahan yang diterima oleh ajaran Islam. Sementara model-model yang lain dieliminasi. al-Qur'an bahkan menegaskan bahwa tanpa adanya akad pernikahan, hubungan seksual antara laki-laki dan perempuan adalah perilaku kriminal (budud) sehingga dikenakan hukuman ḥadd, sebagaimana ditegaskan disebutkan dalam surat al-Nūr ayat 2.

Pola modifikasi ini merupakan bentuk penjembatanan al-Qur'an terhadap adat yang berlaku di masyarakat dengan cara memilah dan memilih adat yang sejalan dengan nilai-nilai syara' dan ada yang tidak sejalan dengan nilai syara'. Pola ini adalah bentuk apresiasi secara kritis dan selektif terhadap adat dengan menerima elemen-elemen adat yang positif (sahih) dan menolak elemen-elemen adat yang tidak negatif (batil). Dalam proses tersebut ada proses penyesuaian dan penggantian sehingga meskipun elemen adat yang positif diterima, namun ada penyesuaian.

\section{Pola adopsi}

Pola adopsi sebenarnya hampir sama dengan pola modifikasi. Keduanya memanfaatkan hukum adat Arab dan meng-Islamkan-nya. Perbedaan keduanya adalah apabila dalam model modifikasi, bentuk formal diubah secara drastis, meskipun perubahan itu menyisakan ruang bagi elemen adat untuk tetap hidup secara terbatas. Dalam pola adopsi dan adaptasi, bentuk formal adat sangat sedikit mengalami perubahan. Perubahan lebih banyak terjadi dalam 
ljtihad, Jurnal Wacana Hukum Islam dan Kemanusiaan, Volume 14, No. 2, Desember 2014: 231-250

tataran kognitif, yaitu dalam aspek pemahaman mengenai tujuan dari adat tersebut.

Contoh paling jelas dari pola penerimaan adat Arab sebagai bagian fikih dalam praktek salam atau salaf. Salam atau salaf adalah bentuk jual beli yang dilakukan dengan membeli barang yang masih berupa karakteristik dan tertanggung dengan biaya di depan, atau sebaliknya. Ketika Rasulullah tiba di Madinah pertama kali, beliau menemukan bahwa salam telah menjadi praktek masyarakat Madinah. Orang-orang Madinah melakukan salam untuk masa setahun atau dua tahun. Rasululllah kemudian bersabda: "Barangsiapa bersalaf (salam), hendaklah ia melakukannya dengan ukuran dan timbangan tertentu, sampai jangka waktu tertentu pula" (Sabiq, 1995, Juz III: 182-183)

Pola yang sama dapat dijumpai dalam tradisi akikah. Akikah adalah adat Arab dalam menyambut kelahiran anak. Apabila seseorang mendapatkan anak, ia menyembelihkan seekor kambing dan melumuri kepala anak tersebut dengan darah kambing itu. Adat tersebut diadaptasi oleh Islam. Nabi Muhammad tidak menghapus tradisi akikah melainkan mengambil alihnya dengan mengubah sedikit elemen formal. Apabila dalam tradisi jahiliyyah, rambut anak dilumuri dengan darah kambing, dengan datangnya Islam beberapa elemen akikah diubah. Rambut yang diakikahi dipotong, lalu kepalanya dilumuri dengan minyak wangi (Rushd, 1989: 798).

Adat-adat yang berasal dari kebiasaan masyarakat Arab banyak yang diiterima oleh syariat sepanjang tidak bertentangan dengan nilai dasar syariat Islam. beberapa persoalan menunjukkan pengaruh adat Arab yang kuat. Khalil 'Abd al-Karim mencatat beberapa persoalan yang memiliki akar dalam tradisi Arab, yaitu tentang khumus (seperlima) bagian rampasan perang, poligami, ruquah, dan lain sebagainya (al-Karim, 1997). Hal itu wajar karena Islam memang dimaksudkan untuk menyempurkan akhlak yang mulia dan mengubah sistem yang sosial yang tidak manusiawi. Elemen-elemen adat yang baik dan telah berjalan di kalangan masyarakat, utamanya dalam persoalan mumalah tetap dipelihara. Hal itu menunjukkan sebuah kebijakan Islam dalam melakukan perubahan sosial.

Khulafa' Rasyidin pun melakukan kebijakan yang sama terhadap adat masyarakat Arab yang baik. 'Ali bin Abi Talib menjual untanya dengan sistem salam, yaitu dia dibayar setelah tenggang waktu tertentu yang telah disepakati. Abu Bakar dan 'Umar bin Khattabb melakukan praktek sewa menyewa yang telah dikenal bangsa Arab. Para sahabat, sebagaimana Rasulullah 
mempraktekkan pula penyelesaian perkara dengan sistem tạ̣kim (arbitrasi). Praktek mudăabah yang telah dikenal masyarakat Arab pra-Islam pun dilakukan oleh para sahabat seperti 'Umar dan 'Ali (Faruqi, 1992: 483-484).

\section{Posisi adat dalam $u s \underline{u} l$ fiq}

Dalam usūl fiqh, adat dimasukkan dalam dalil hukum atau sumber oleh sebagian ulama. Karena itu, adat dipandang sebagai dalil hukum yang diperdebatkan legitimasinya. Karya uṣul fiqh klasik sangat jarang memuat pembahasan mengenai adat atau 'urf dalam konteks dalil hukum. Informasi tentang adanya pengakuan adat sebagai dalil hukum disampaikan oleh ahli hukum Hanbali, Najm al-Din al-Tufi. Al-Tufi mendata berbagai dalil hukum yang dikenal di masanya, baik yang disepakati maupun diperselisihkan. Ia mendata adanya 19 dalil hukum yang dikenal, dan salah satunya adalah 'urf atau adat (al-Tufi, 1998: 238).

Pengambilan adat sebagai dalil hukum dapat dilihat akarnya di kalangan fukaha Malikiyyah dan Hanafiyyah. Mereka menganggap adat sejalan dengan dalil syar'i bahwa apa yang dipandang baik oleh umat Islam, maka menurut Allah juga baik. oleh karena itu, lahirlah kaidah الثابت بالعرف العحيح غير الغاسد ثابت بليل شرغي (apa yang tetap berdasarkan 'urf yang sahih, tidak negatif, maka seperti tetap berdasarkan dalil shar $\bar{\imath}$ (Zahrah, tth: 273).

Pembahasan adat atau 'urf justru terdapat dalam karya qawä id fiqhiyyah, yang kaidahkaidah terhadap persoalan furū' Adat diakui sebagai salah satu kaidah mayor atau kaidah utama dalam kaidah fikih. Pengakuan secara lebih terbuka terhadap arti penting adat muncul dalam kitab-kitab kontemporer. Tokoh-tokoh ușul fiqh kontemporer, seperti 'Abd a-Wahhab Khallaf, Muhammad Abu Zahrah, dan 'Abd al-Karim Zaidan memasukkan adat sebagai bagian dari dalil hukum.

Adat diakui sebagai salah satu dalil hukum, yang masuk dalam kategori dalil 'aqTi (rasional). Pembahasan mengenai adat dalam uṣul figh merupakan bagian dari dinamika hukum Islam dalam tataran praktis. Secara teoritis, hukum dalam ușül fiqh dipahami sebagai "Firman Tuhan yang terkait dengan perbuatan mukallaf (subyek hukum), baik berupa tuntutan perbuatan, pilihan, maupun penentuan seperangkat tanda hukum (Khallaf, 1978: 100)." Jadi, hukum berasal dari Allah, sebagai satu-satunya pihak yang berwenang atas legislasi hukum. 
Ijtihad, Jurnal Wacana Hukum Islam dan Kemanusiaan, Volume 14, No. 2, Desember 2014: 231-250

Nilai-nilai dasar Islam memang meliputi seluruh persoalan hidup, tetapi aturan-aturan praktis hukumnya tidak sebanyak persoalan yang berkembang masyarakat. Karena itu, para ahli hukum Islam memandang bahwa adat masyarakat merupakan salah satu pilihan ketika aturan praktis dari al-Qur'an, sunnah, maupun hasil analogi tidak ditemukan dalam menjawab persoalan. Adat bahkan dapat digunakan untuk mentakhsis (takhșis adalah lex specialis derogat lex generalis) hukum-hukum yang berasal dari nash yang bersifat umum dan taraf kekuataannya hanyalah zann (praduga kuat).

Adat awalnya banyak digunakan oleh kalangan Malikiyyah dan Hanafiyyah. Kedua aliran hukum tersebut adalah representasi dari aliran hukum Islam klasik yang berbasis kepada tradisi hukum di kota-kota besar Islam, yaitu Madinah dan Kufah. Adat bisa masuk ke dalam hukum Islam melalui beberapa cara. Di kalangan Malikiyyah dikenal adanya 'amal abl al-Mad̄inah (praktek orang-orang Madinah) dan qiyas, di kalangan Hanafiyyah dikenal adanya istị̣san, yaitu penggunaan pilihan rasional untuk mencari hukum yang paling sesuai dengan maslahah (Kamali, 1991: 285). Baik 'amal abl al-Madinab maupun istiḅsān memungkinkan adat digunakan sebagai sumber untuk merumuskan hukum yang sesuai dengan kemaslahatan manusia.

Dalam istị̆sān, misalnya dikenal adanya istiḅsān yang berdasarkan adat. Istihsan berdasatkan adat adalah praktek tidak melakukan ketentuan umum yang menjadi dasar qiyas karena pertimbangan praktis. Salah satu rukun akad jual beli dalam ketentuan syariat harus jelas kadarnya. Ketika ketentuan umum akad itu diberlakukan kepada berbagai ragam bentuk akad, semua jual beli, baik barang maupun jasa, harus jelas kadarnya.

Pada prakteknya, ulama Hanafiyyah tidak memberlakukan ketentuan semacam itu dalam kasus penggunaan kamar mandi umum. Kebiasaan dalam penggunaan kamar mandi umum adalah pemberian uang untuk memanfaatkan kamar mandi umum, tanpa adanya kejelasan kadar waktu di kamar mandi dan kadar air yang dipergunakan. Berdasarkan analogi dari ketentuan umum tentang kejelasan kadar, hal itu salah. Akan tetapi, berdasarkan istiḥsān, yang melihat nilai maslahah dalam syariat sebagai bahan pertimbangan, praktek jual beli semacam itu diperbolehkan (Zuhaili, 1986, Juz II: 745).

Dengan demikian, adat menjadi sebuah sumber dalam penetapan hukum ketika adat tersebut merepresentasikan tujuan syariat dan tidak bertentangan dengan satu nash pun. 
Legitimasi penggunaan adat sebagai sumber hukum antara lain didasarkan atas dalil shar $i>$ dan tujuan syariat.

Beberapa ayat al-Qur'an menyebutkan perintah Allah untuk memerintahkan yang ma'ruf (diketahui baik) atau adat, seperti dalam surat A $\bar{i}$ 'Imrān 114/115 dan al-A'rā́f 199. Makna al-äadah dalam surat al-A'rāf 199 dan al-ma'rüf dalam surat Ali 'Imrān 114/115 umumnya dipahami sebagai sesuatu yang berdasarkan al-Qur'an dan hadis. Akan tetapi berdasarkan penunjukan lafalnya, keduanya bisa merujuk kepada kebiasaan yang baik di masyarakat (Kamali, 1991: 283-284).

Legitimasi adat diperoleh pula dari tujuan umum syariat, yaitu merealisasikan kemaslahatan manusia dan mencegah kemudharatan. Realisasi maslahah tersebut bisa terkait dengan kebutuhan dasar manusia (maslahah daruriyah), kebutuhan sekunder manusia (maslahah häjizab), dan kebutuhan tersier manusia (maslahah tahsiniyyah). Pemeliharaan kebutuhan dasar manusia, yaitu agama, keselamatan jiwa, kehormatan dan keturunan, akal, dan harta, meniscayakan semua praktek yang mampu merealisasikan kemaslahatan tersebut dapat dipandang sebagai bagian absah ajaran Islam. Prinsip utama penggunaan maslahah mursalah adalah bahwa maslahah yang dimaksud harus bersifat 1) umum, yaitu terkait dengan kepentingan publik, 2) hakiki, yaitu benar-benar berupa kemaslahatan bagi umat manusia, bukan mad̦arat yang berbungkus kemaslahatan, dan 3) tidak menyalahi nașṣ al-Qur'an dan sunnah (Khallaf, 1978: 86-87).

Sebagai saringan adat agar benar-benar sesuai dengan syariat Islam, dalam usül fiqh dikenal pembagian adat sahih (benar) dan adat $\overline{f a s i d}$ (negatif). Adat sahih adalah adat yang tidak menghalalkan yang haram dan mengharamkan yang halal. Sementara itu, adat fasid adalah adat yang menghalalkan yang haram dan mengharamkan yang halal (Zuhaili, 1986, Juz II: 829-831). Dalam persoalan mumalah, pembagian tersebut dapat dibaca dalam logika " tidak bertentangan". Sebuah adat dipandang sahih karena tidak bertentangan dengan dalil shar iatau nash. Nilai shar $\bar{i}$ sebuah adat dikembalikan kepada kesesuaian nilai dasar syariat yang terwujud dalam maqāsid shariyyah di atas, bukan kepada dalil-dalil nașs yang parsial.

Tidak berhenti di situ, adat juga menjadi landasan pemaknaan terhadap lafal-lafal alQur'an maupun hadis. Salah satu makna hakiki lafal adalah berdasarkan makna 'urfi (makna berdasarkan kebiasaan pengguna bahasa). Makna 'ur $\bar{i}$ adalah makna yang didasarkan atas 
ljtihad, Jurnal Wacana Hukum Islam dan Kemanusiaan, Volume 14, No. 2, Desember 2014: 231-250

penggunaan makna aktual dari sebuah lafal di masyarakat, bukan lagi makna dasarnya (alSyirazi, 1985: 6). Hal itu menunjukkan bahwa pemaknaan bajāini (lughawin) yang menjadi landasan kaidah-kaidah ushul bayāini bersandar pula kepada makna yang menjadi konvensi masyarakat pengguna bahasa.

\section{Posisi adat dalam kaidah fikih}

Kaidah fikih berisi kaidah-kaidah untuk memecahkan persoalan praktis. Kaidah fikih membimbing para otoritas hukum untuk memecahkan persoalan praktis yang tidak ada landasan dalilnya. Berbeda dengan kaidah ușul yang bersifat deduktif, kaidah fikih bersifat induktif karena diambil dari pemecahan hukum Islam yang telah ada. Kaidah fikih dalam kasus adat adalah penjabaran dalam tataran praktis penerapan kaidah usül (al-Nadwi, 1991: 59-60).

Adat dalam kaidah fikih mendapatkan perhatian karena adat membentuk kaidah mayor dalam kaidah fikih. Kaidah mayor yang terkait dengan adat adalah:

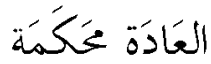

Adat menjadi landasan penetapan hukum

Kaidah tersebut akan dapat dipahami posisinya melalui pemahaman mengenai hubungan adat dan syariat dalam kaidah fikih. Berbagai adat dalam hubungannya dengan syariat dapat dibagi menjadi tiga:

Pertama, Adat yang telah ada sebelum Islam dan kemudian diadopsi dan dikukuhkan oleh syariat, seperti hukum diyat dan tawaf, atau adat yang baru tercipta dengan lahirnya Islam, seperti tahärah dan ḅijä.

Kedua, Adat yang tidak dikukuhkan oleh hukum shar ${ }^{\bar{i}}$, tetapi menjadi bagian dari pelaksanaan hukum shari, seperti penentuan masa haid, besarnya mas kawin, dan dan penentuan akil baligh akibat perbedaan iklim. Adat-adat demikian diangkat menjadi bagian dari hukum shari, yang masih bisa menerima perubahan. Dalam hukum-hukum yang termasuk kategori inilah kaidah perubahan hukum berlaku. Kebiasaan yang terkait dengan murü'ah (keperwiraan dan kesopanan), misalnya, berbeda-beda menurut tempatnya. Di Iraq, murü'ah ditandai dengan mengenakan tutup kepala. Orang yang tidak memakai tutup kepala 
tergolong tidak menjaga murü'ah. Sementara itu, di beberapa wilayah Afrika, tutup kepala tidak menjadi ukuran murü'ah.

Ketiga, Adat yang tidak termasuk hukum shar $i$ dan tidak menjadi gantungan pelaksanaan hukum sharí. Adat semacam itu dibagi lagi menjadi dua: 1) adat yang dalam batas kebolehan shar'idan 2) adat yang tidak selaras dengan nash yang bersifat umum. Adat yang kedua menjadi perbedaan pendapat para ulama. Bagi kalangan Hanafiyah, adat semacam itu berfungsi sebagai takhșis (pengecualian atau lex specialis derogat lex generalis) terhadap makna nașs yang masih umum. Bagi mayoritas ulama, adat demikian tidak diterima (Permono, 2002: 22-24).

Adat dalam kategori kedua di atas banyak mendapatkan perhatian di kalangan ahli hukum Islam. Al-Suyuti mencatat berbagai persoalan hukum Islam yang melibatkan visi adat dalam kategori kedua, antara lain: penentuan lama haidl, penentuan usia baligh, lama nifas, perbuatanperbuatan yang membatalkan salat, najis-najis ma' $\bar{f}$ (yang dimaafkan), lamanya jeda yang diperbolehkan antara satu perbuatan wudlu dengan perbuatan wudlu lain, mengambil buah yang jatuh dari pohon, batasan harta terjaga yang membuat tindakan mengambilnya menjadi kasus pencurian, pemberian fasilitas pelana dalam sewa menyewa binatang tunggangan, dan persoalan timbangan dan ukuran, dan rotasi atau waktu pergantian hakim atau penguasa (alSuyuti, T.th.: $63 \mathrm{dst}$ ).

Karena pentingnya posisi adat, para ulama, membuat kaidah-kaidah yang terkait dengan posisi adat dan penggunaannnya dalam level praktis. Beberapa kaidah fikih penting yang

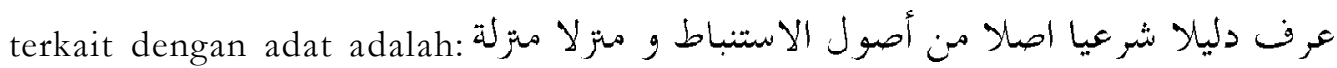
الشَ (Adat adalah dalil shar ${ }^{\bar{T}}$ dan menjadi sumber pengambilan hukum, serta menempati posisi syarat);

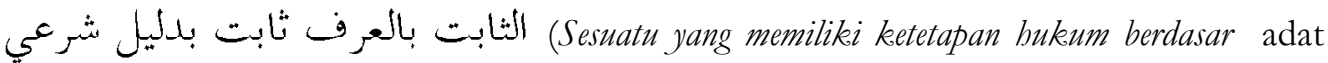

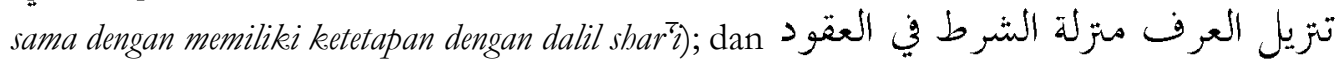
('Uruf menempati posisi syarat dalam akad) (Zuhaili, 1986, Juz II: 832).

Singkatnya, adat memiliki peran penting dalam penjabaran dan pelaksanaan hukum Islam. Keberadaan adat menjadikan sebuah hukum lebih bisa memenuhi rasa keadilan karena dalam di masyarakat, nilai yang diyakini bersama lebih menjamin kesepakatan. Penggunaan nalar ( $\left.r a^{\prime} y\right)$ dalam sejarah hukum Islam seringkali didasarkan pula atas pertimbangan adat. 
ljtihad, Jurnal Wacana Hukum Islam dan Kemanusiaan, Volume 14, No. 2, Desember 2014: 231-250

Penggunaan adat tersebut tentunya dibatasi dengan ketentuan, pertama bahwa adat tidak boleh bertentangan dengan nash. Adat tidak dipergunakan apabila telah ada penjabaran hukum dari dalil yang manșuș (didasarkan nașs). Sebesar apapun peran adat dalam hukum Islam, ia bukan sumber hukum yang mendiri, melainkan harus disesuaikan dengan spirit dan pesan Al-Qur'an dan sunnah Rasulullah. Kedua, sebuah adat berlaku secara umum dan dipratekkan secara luas oleh masyarakat, kecuali adat yang menyangkut kebiasaan pribadi, seperti lama masa haid bagi masing-masing perempuan.

\section{Adat dalam dunia peradilan Islam}

Penggunaan adat dalam dunia peradilan telah terjadi semenjak masa Rasulullah. Rasulullah sejak awal karirnya dikenal sebagai seorang hakam (arbitrator) yang baik sehingga beliau mendapat gelar al-Amin (yang dapat dipercaya). Karena itu, tidak jarang orang-orang nonmuslim pun mengadukan kasus persengketaannya kepada Rasulullah (Watt and Bell, 1991:26).

Para sahabat pun mempergunakan model adat yang ada untuk memecahkan masalah yang muncul. 'Umar bin Khattab, misalnya, pernah menyewa kuda dengan syarat salah satu temannya ikut naik bersamanya. Ketika pemilik kuda terluka, ia meminta kompensasi dari 'Umar. 'Umar kemudian memintanya untuk memilih arbitrator untuk menyelesaikan sengketa berdasarkan praktik umum yang ada. Pemilik kuda memilih Shuraih dan 'Umar pun menyetujuinya. Ketika Syuraih memberikan keputusan yang memenangkan pemilik kuda, 'Umar menerima kekalahannya dengan membayar sejumlah uang yang diminta (Faruqi, 1992: 483-484).

Ibnu Farhun, seorang ahli hukum Maliki dan penulis kitab tentang peradilan Islam Tabsirah al-Hukkam, memberikan sebuah penjelasan mengenai posisi adat di dunia peradilan pada Bāb al-Qada bi al-'urf wa al-'Adah (Pasal Mengenai Pengadilan dengan 'urf dan adat). Ia berpendapat bahwa ketika seorang hakim harus memilih 1) makna literal suatu kata atau 2) bagaimana makna itu digunakan dalam masyarakat, ia menganjurkan untuk menggunakan yang kedua. Ia menunjukkan bagaimana adat menjadi landasan hakim dalam penetapan hukum, seperti dalam kasus jual beli dan persoalan rumah tangga, antara suami dan isteri. Salah satu contohnya adalah tentang klaim isteri bahwa ia telah disetubuhi oleh suaminya 
setelah keduanya berkhalwat (berduaan sendiri di tempat sunyi). Klaim isteri tersebut diterima berdasarkan ukuran adat bahwa ketika suami isteri berduaan di tempat sunyi, maka hubungan badan biasa terjadi (Farhun, 2003, Juz II: 27-30).

Penggunaan adat juga diakui oleh ulama Hanafi. Ibnu Nujaim (w. 970 H), misalnya, menegaskan penggunaan 'urf dalam penetapan masalah perdata yang dibawa ke pengadilan. Ia memberikan contoh mengenai transaksi bisnis, misalnya, ketika mata uang yang digunakan dalam kesepakatan bisinis tidak disebutkan saat sebuah kontrak dibuat, maka mata uang tersebut ditentukan berdasarkan kebiasaan - yaitu mata uang yang digunakan di pasar. Jika di pasar ada beberapa mata uang yang beredar, maka mata uang yang paling banyak digunakan dan diterima para pengusahalah yang dipandang patut dipergunakan (Nujaim, 1993: 94-95).

Perbedaan adat tersebut dapat mengakibatkan perbedaan fatwa atau putusan pengadilan. Imam Syafi'i ketika pindah ke Mesir mengeluarkan fatwa-fatwa baru (qawljadid) yang berbeda dengan fatwa-fatwanya ketika masih di Iraq (qawl qadim), meskipun secara eksplisit ia tidak menerima kehujjahan adat. Perubahan fatwa tersebut terjadi karena perubahan tempat dan budaya. Karena itu, Ibnu Farḥūn mengingatkan agar seorang mufti (pemberi fatwa), yang pindah ke negeri yang memiliki tradisi berbeda dengan negeri sebelumnya, tidak memberikan fatwa sampai ia benar-benar memahami kebiasaan dan konvensi yang ada di negeri tersebut (Faruqi, 1992: 494).

Hal senada disampaikan oleh Khatib al-Baghdadi seorang pengikut Syafi'i. Ia menegaskan bahwa mufti dan hakim harus sadar akan keberadaan kebiasaan dan tradisi masyarakatnya. Tanpa kesadaran tersebut, mereka tidak akan mampu memahami kasus-kasus dalam perspektif yang sepatutnya sehingga beresiko membuat keputusan hukum yang tidak sepatutnya (Faruqi, 1992: 495).

Ibnu Nujaim memberikan bahasan mengenai pengambilan gaji seorang hakim (qāạ $\bar{\imath})$. Ia mengutip pendapat bahwa hakim berhak mengambil gaji di masa reses (tidak menangani kasus), sebagaimana halnya para pengajar. Alasannya adalah masa reses tersebut adalah saat untuk beristirahat dan saat belajar bagi orang-orang yang memiliki semangat belajar tinggi (Nujaim, 1993: 95-96). Hak tersebut didasarkan atas kebiasaan setempat karena ada kalanya masa reses mengganggu tugas. Karena itu, hak gaji didasarkan atas kebiasaan yang berlaku. 
Kajian adat oleh Ibnu Nujaim juga menyangkut kompetensi mengadili dan hadiah bagi hakim. Untuk kasus pertama, ia mencontohkan kasus ketika anak yatim yang berasal dari suatu negeri mewakafkan hartanya yang berada di negeri lain dan mensyaratkan pengawasan hakim. Apakah hakim yang ditunjuk adalah hakim tempat anak yatim tinggal atau hakim tempat harta yang diwakafkan itu berada. Menurutnya yang paling logis adalah memilih hakim tempat harta itu berada karena ia lebih tahu dengan kemaslahatan harta tersebut. Kemaslahatan itulah yang menurutnya dikehendaki oleh waqif/pemberi wakaf (Nujaim, 1993: 102).

Adapun kasus kedua, yaitu penerimaan hadiah oleh hakim, utamanya sebelum penunjukkannya sebagai hakim dalam kasusnya. Menurut Nujaym penerimaan tersebut dapat dibenarkan bagi masyarakat yang memiliki adat demikian. Menurut Ibnu Nujaim, pembenaran adat demikian adalah sepanjang pemberian itu tidak melampaui adat atau kebiasaan. Apabila pemberian tersebut melampaui kebiasaan, kelebihan pemberian itu harus dikembalikan (Nujaim, 1993: 94).

\section{Prospek adat}

Sejarah perkembangan hukum Islam di atas menunjukkan bagaimana adat memainkan peran penting dalam memecahkan persoalan praktis di masyarakat. Peran adat di atas berada dalam dua level, pertama adalah level pengambilan kebijakan oleh otoritas negara, dan kedua adalah level penerapan aturan. Pada kedua level tersebut, adat atau adat menjadi bahan pertimbangan dalam membuat rumusan hukum. Hukum yang adil adalah hukum yang mampu mewadahi nilai-nilai luhur masyarakat dan tanggap terhadap dinamika masyarakat. Adat merupakan cerminan dari nilai luhur masyarakat dan dinamika yang ada di dalamnya.

Dengan semakin kuatnya arus modernitas, otoritas tradisional yang menyangga adat semakin berkurang legitimasinya. Dalam masyarakat tradisional, keperluan pemecahan masalah hukum sebagian dipenuhi oleh otoritas tradisional. Menurut Weber, otoritas tradisional adalah otoritas yang bersandar kepada legitimasi tradisional, yaitu kepercayaan yang mapan terhadap kesucian tradisi masa lalu dan legitimasi orang-orang yang melaksanakan otoritas tersebut (dalam Thompson and Thunstall, 1977: 68-69). Jadi, semakin maju 
masyarakat akibat modernisasi pada dasarnya semakin lemah otoritas tradisional dan semakin kuat otoritas rasional, yaitu otoritas yang bersandar kepada legitimasi legal-rasional, yaitu yang berpijak kepada legalitas pola aturan normatif. Otoritas legal-rasional tersebut berbasis pada nilai yang impersonal, yaitu yang dibuat oleh lembaga berwenang.

Menguatnya otoritas legal-rasional dalam sistem hukum bernegara ditunjukkan dengan semakin kuatnya aturan-aturan formal dan hukum positif. Berbagai hubungan sosial, semakin lama semakin banyak yang diatur oleh aturan formal. Hal itu bisa berdampak positif karena menunjukkan sebuah tren ke arah masyarakat dengan budaya hukum yang kuat.

Akan tetapi, budaya hukum tidak bisa digantungkan kepada aturan formal semata. Di negara-negara yang maju, ketertiban masyarakat justru terlihat karena adanya budaya hukum yang kuat. Adat masyarakat mendukung sebuah sistem di mana hukum nasional menjadi pijakannya, tetapi hukum itu dijalankan bukan karena takut akan sanksi, melainkan karena telah menjadi cara hidup.

Di Indonesia, budaya demikian belum terbangun secara memadai. Masyarakat Indonesia berada dalam transisi dari masyarakat tradisional ke masyarakat modern. Setelah merdeka lebih dari lima puluh tahun, hukum positif semakin menguat, tetapi masyarakat juga masih banyak berpegang kepada tradisi dan bersandar kepada otoritas tradisional.

Dalam situasi tersebut, adat bisa kontraproduktif dengan upaya penegakan hukum. Pada prakteknya, masih banyak terjadi nikah sirri (nikah tidak tercatat) dengan alasan bahwa pernikahan adalah lembaga yang bisa diselenggarakan tanpa keterlibatan otoritas negara. Keabsahan pernikahan cukup didasarkan atas otoritas ahli agama dan kesesuaian dengan adat masyarakat. Di sisi lain, mengabaikan peran adat juga tidak memecahkan segala persoalan. Penyelesaian kasus hukum melalui jalur litigasi pada kenyataannya belum mampu menjangkau seluruh persoalan di masyarakat. Penciptaan masyarakat sipil meniscayakan pemberdayaan masyarakat untuk turut serta mengatasi problem sosial. Karena itu, saat ini muncul alternative dispute resolution (ADR), seperti arbitrasi, resolusi, dan mediasi. ADR menjadi saluran untuk membantu penciptaan masyarakat hukum sehingga kasus-kasus hukum tidak berujung kepada konflik sosial atau kekerasan karena tidak tertanganinya banyak kasus hukum akibat terbatasnya kemampuan lembaga peradilan menangani seluruh persoalan hukum yang kompleks di masyarakat. 
Ijtihad, Jurnal Wacana Hukum Islam dan Kemanusiaan, Volume 14, No. 2, Desember 2014: 231-250

Adat pada taraf tertentu masih diperlukan sebagaimana otoritas tradisional saat ini masih diperlukan. Otoritas tradisional tersebut bekerja berdasarkan adat yang hidup di masyarakatnya, yang dikenal juga dengan local wisdom. Untuk masyarakat Indonesia, pembangunan budaya hukum tanpa mempertimbangkan local wisdom akan mengurangi legitimasi hukum formal itu sendiri. Karena itu, pemahaman local wisdom, termasuk agama di dalamnya, menjadi bagian penting dalam mencipakan ketertiban di masyarakat.

Bagi para hakim, adat bisa menjadi bahan pertimbangan dalam pencarian hukum (recht finding) guna pemecahan kasus-kasus di lapangan. Pemahaman terhadap adat akan membantu pencarian keadilan. Pemecahan kasus hukum dengan hanya bersandar kepada hukum formal benar adanya, tetapi dalam kasus-kasus tertentu pemahaman mengenai tradisi masyarakat akan sangat membantu dalam mencapai keputusan yang adil dan dapat diterima semua pihak.

Yang patut dicatat adalah bahwa adat dalam hukum Islam menjadi penjelas operasional dalam kasus-kasus perdata. Karena wilayah hukum Islam (fikih) adalah perbuatan mukallaf, maka persoalan adat terbatas kepada persoalan-persoalan tentang pengaturan perilaku mukallaf. Adat dalam pembahasan hukum Islam tidak merambah wilayah adat dalam pengertian ritus dan keyakinan masyarakat lokal, yang mungkin masih diperdebatkan oleh umat Islam. Oleh karena itu, pembahasan mengenai adat dalam hukum Islam tidak memiliki implikasi terhadap pengakuan maupun penolakan ritus-ritus tertentu karena ritus yang berlaku di masyarakat mengandung dimensi tumpang tindih antara wilayah keyakinan (akidah) dan wilayah mumalah.

\section{Penutup}

Akar penerimaan maupun seleksi adatdalam hukum Islam bisa dilacak pada masa awal pembentukan hukum Islam, yaitu masa Nabi Muhammad. Al-Qur'an dan hadis memainkan peran penting dalam membatalkan, mengubah, atau menerima adat yang hidup di masyarakat Arab saat itu. Berbagai kasus menjadi cobtoh bagaimana terjadi apresiasi adat dalam pembentukan hukum Islam, namun apresiasi tersebut dilakukan secara kritis sesuai dengan parameter ajaran Islam. 
Pada perkembangannya, posisi adat menjadi lebih jelas ketika kajian ushul fikih memasukkan adat sebagai salah satu dalil hukum yang diperselisihkan. Meskipun fenomena tersebut lebih jelas dalam kajian ushul fikih kotemporer, tetapi penerimaan adat sebagai dalil hukum telah terjadi semenjak lama. Adat diakui sebagai penjabaran hukum Islam secara lebih praktis. Kaidah fikih bahkan lebih tegas memasukkan adat sebagai dasar hukum dalam satu satu kaidah terkenal al-'ádah muḥakkamah. Pada prakteknya, adat digunakan juga dalam dunia peradilan untuk membantu hakim dalam menemukan hukum. Kebiasaan bisa menjadi parameter untuk penyelesaian masalah-masalah perdata.

Pada era sekarang, keberadaan adat masih penting sepanjang masyarakat tradisional dan otoritas tradisi tetap menjadi rujukan masyarakat untuk menemukan pemecahan masalah mereka. Adat bisa menjadi sandaran dalam pemecahan masalah praktis sepanjang sejalan dan tidak bertentangan dengan nilai-nilai Islam lainnya. Relevansi adat dalam hukum Islam terletak kepada fungsinya dalam menjabarkan dan mencari panduan penerapan hukum Islam dalam tataran yang lebih operasional, khususnya persoalan perdata. Adat dalam hukum Islam tidak memiliki kaitan pembahasan dengan ritus atau praktik religi masyarakat lokal. Persoalan ritus adalah wilayah yang bersinggungan antara wilayah muamalah dan keyakinan (akidah) sehingga memerlukan kajian tersendiri.

\section{Daftar Pustaka}

Al-Jauziyyah, Ibn Qayyim. Badă'i' al-Fawā'id. Beirut: Dār al-Kutub al-'Ilmiyyah. Cet. II, 1994. Al-Karim, Khalil 'Abd. al-Juzur al-Tarikhiyyah li al-Syǟ' ah al-Istamiyyah. Kairo: Sinā li al-Naṣr, 1997.

Al-Nadwi, 'Ali Aḥmad. al-Qawā 'id al-Fiqhiyyah: Mafhümuhāa, Nasy'atuhā, Tatawwuruhā, Dirāsah

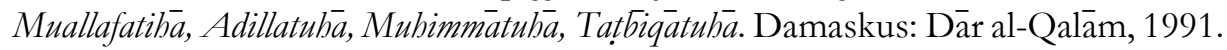

Al-Sabuni. Muhammad 'Ali. Tafsir Āyat al-Aḅkäm min al-Qứán. Beirut: Dār al-Kutub al'Ilmiyyah. Cet. I, 1999.

Al-Syaukani, Muhammad bin 'A $\overline{l i}$ bin Muhammad. Fatḥ al-Qađ̄ir, al-Jami' bayn al-Riwāyah wa al-Dirāah min 'Tlam al-Tafsir. Beirut: Dār al-Kutub al-'Tlmiyyah, 1994.

Al-Syirazi, Abu Ishaq. al-Luma' $\bar{f} i$ Ușul al-Fiqh. Beirut: Dār al-Kutub al-'Tlmiyyah, 1985

Al-Suyuti, Jalal al-Din. al-Asybāh wa al-Nažă ir f̄i al-Furū' Beirut: Dār al-Kitāb al-Islāmi, T.th. Al-Tufi, Najm al-Din. Kit̄ab al-Táyin f̄i Syarḥ al-Arbāin. Beirut: Mu'assasah al-Risālah, 1998. 
ljtihad, Jurnal Wacana Hukum Islam dan Kemanusiaan, Volume 14, No. 2, Desember 2014: 231-250

Coulson, Noel James. A History of Islamic Law. Edinburgh: Edinburgh University Press, 1960.

Faruqi, Muhammad Y. "Consideration of 'Urf in the Judgement of khulafa' Rasyidun and the Early Fukaha" The American Journal of Islamic Social Science. Vol. 9 No. 4 (1992).

Ibn Rusyd, Abu Walid Muhammad. Bidāalah al-Mujtabid wa Nihāyah al-Muqtasid. Beirut: Dār al-Jamil, 1989.

Ibnu Farhun, Burhan al-Din Abu al-Wafa'. Tabsirah al-Hukkéam fï Ușul al-'Aqdiyyah wa Manahij al-Aḥkàm. Riyāẹ: Dār 'Ālim al-Kitāb. 2003. Juz II

Ibnu Nujaim. Al-Asybāh wa al-Nažàir 'ala Mažhab Abü Hạnifah al-Nu'mān. Beirut: Dār alKutub al-'Ilmiyyah. 1993

Kamali, Mohammad Hashim. Principles of Islamic Jurisprudence. Cambridge: The Islamic Text Society. 1991

Khallaf, 'Abd al-Wahhab. 'Tlm Ușü al-Fiqh. Kuwait: Dār al-Qalam. 1978

Sabiq, Sayyid. Fiqh al-Sunnah. Kairo: Dār al-Fath li al-A’lām al-'Arabī. 1995. Juz II

Sjechul Hadi Permono. Dinamisasi Hukum Islam dalam Menjawab tantangan Globalisasi. Ttp: Demak Press. 2002.

Watt, Montgomery dan R. Bell. Introduction to the Quran. Edinburgh: Edinburgh University Press. 1991.

Weber, Max. "Power and Birocracy", selected reading edited by Kenneth Thompson and Jeremy Thunstall dalam Sociological Perspective: Selective Reading. Middlesex: Penguin Book Ltd. 1977.

Zahrah, Muhammad Abu. Ușül al-Fiqh. T.tp.: Tp., T.th.

Zuhaili, Wahbah. Ușü al-Figh al-Istamìi. Beirut: Dār al-Fikr. Cet. I. 1986. Juz. II. 